\title{
Repositioning Literacy Education Programme for Entrepreneurial Development in Rivers State, Nigeria
}

\author{
Olori, Christian N. PhD'1 \\ Olori, Gloria l.2 \\ ${ }^{1}$ Department of Adult Education \& Extra-Mural Studies, University of Nigeria, Nsukka; Email: oloricon@yahoo.com \\ 2Department of Vocational Education, University of Uyo, Uyo; Email: gloriaolori@yahoo.com
}

\author{
Doi:10.5901/jesr.2016.v6n2p177
}

\begin{abstract}
The continuous rise in the number of unemployed teeming youth searching for white collar jobs in Rivers State necessitated this study by the researchers on the need to reposition literacy education programme for entrepreneurial development. This study therefore attempts to investigate how literacy education programme can be repositioned for entrepreneurial development in Rivers State. It adopted a descriptive survey research design with a population of 1,231 respondents made up of facilitators and learners in 18 centres from three selected local government areas of the state. Out of the population, 302 respondents were purposively drawn to respond to the Questionnaire on Repositioning Literacy Education Programme and Entrepreneurial Development. The reliability coefficient of .83 was obtained after a trial test using the Cronbach Alpha. Data were analysed descriptively as well as inferentially. Findings revealed that the teaching of entrepreneurial skills in literacy education programme in Rivers State was poor. Findings further indicated that literacy education programme has significantly contributed in teaching-learning of entrepreneurial skills in Rivers State. Significant difference was not found between the responses of facilitators and learners on the extent entrepreneurial skills were taught in the programme. There was significant difference found between the relevance of the programme and the teaching and learning of entrepreneurial skills. Based on the findings, some recommendations were made among them were that organisers of literacy education programme should ensure entrepreneurial skills enshrined in literacy curriculum be taught and government should ensure compliance through adequate monitoring and supervision of content of literacy education programme delivery.
\end{abstract}

Keywords: Literacy, literacy education, entrepreneurship, development

\section{Introduction}

The development of entrepreneurial skills in recent time has been given serious attention by scholars and education practitioners owing to its enormous contribution in the fight against poverty through the acquisition of practical skills. On the other hand, literacy education is conceived as a vehicle aimed at providing these skills to clientele in order to make them become self-reliant. To this end, attempt is made to carefully examine various views of these concepts from wider perspectives of scholars, and analytically articulate some measures for repositioning literacy education with a view to achieving entrepreneurial development.

\section{Review Literature}

Literacy in recent time has been subjected to various debates. It encompasses a wide range of more complex and diverse skills and understanding that is affected by time, place and culture. Indabawa (1995) referred to it as the ability to acquire the skills of reading, writing and numeracy in local or foreign language for effective and efficient functioning of individuals in the activities they involve themselves in the society. Thus, literacy is seen as a human right, a tool for personal empowerment and social development. The importance of literacy was captured by Kaufman and Kraay (2008) that it is the heart of basic Education for All (EFA) and essential for eradicating poverty, reducing child mortality, curbing population growth, achieving gender equality and ensuring sustainable development, peace and democracy.

Giving credence to this statement, UNESCO (2014) posited the usefulness and benefits of literacy as helping learner to get knowledge and skills that are useful in everyday life activities, helping learners to communicate to people especially in writing, giving the learner a feeling of self confidence, personal security and freedom from being cheated or exploited. It further helps the individual to actively participate in politics, increases one's economic, political and social 
gains, and helps the individual to operate new machines (such as the ATM). No wonder, Omoruyi and Omage (2013) noted that the purpose of literacy is the liberation of man from the restrains and limitations of ignorance and dependence. A cursory look at these benefits shows that literacy education programme is capable of raising the consciousness of individual to be more aware of the fundamental problems in their locality and lives, and the extent they are motivated to improve their conditions.

In the midst of crises confronting the individual, literacy education is seen as a tool for instilling skills, knowledge and disposition that will help in the alleviation of issues confronting them. The skills, knowledge and disposition provided for creativity and innovation provided by literacy education is best referred to as entrepreneurship education. Entrepreneurial education helps in the development of entrepreneurial problems solving skills that are used in addressing personal and social challenges.

Entrepreneurial skills development according to Anho (2011) involves a process of human capacity building through formal and/or informal training, inculcating the entrepreneur basic skills such as financial skills, technical skills, creative skills, managerial skills, marketing skills, communication skills and technological skills. This further presupposes that entrepreneurial skills development is multifaceted and addresses situational needs through the application of literacy. In integrating formal and informal aspects of training, many values are deduced to both individuals as well as the nations. Thus, UNESCO (1997) posited that entrepreneurship education has the following values;

1. It helps in the orientation of individual towards innovation. It also produces individuals who are capable of foreseeing the future needs arising from new ways of thinking.

2. It creates awareness to the fact that the key to development is human resources. It further enphasises the need to human abilities, change their values and attitudes in order to accelerate the process of development.

3. It emphasises entrepreneurship as a significant variable in the development process and points it out as a career option. It instills in the youth a longer need to achieve a larger segment of the population.

Consequently, entrepreneurship education encapsulates programmes that promote entrepreneurship awareness and knowledge for career purposes, business creation and development.

Three essential ingredients are notable in the definition of entrepreneurship education by scholars. These attributes include; creativity, innovation and entrepreneurship. Creativity is the ability to create all kinds of ideas needed for decision making innovation. On the other hand, it entails the ability to find value in selected ideas. The development of a business from innovative ideas is termed entrepreneurship. Adewutsi, (2009) lends credence to entrepreneurship when he sees it as being able to identify business opportunities and mobilise economic resource to initiate a new business or revive an existing business under the conditions of risk and uncertainties for the purpose of making profit under private ownership. It is also a process whereby individuals used organised efforts and means to pursue opportunities, to create value, and growth to satisfy needs and wants through innovative and distinctive ways defying all odds (Coulter, 2001).

Accordingly, the importance of literacy education to entrepreneurship development is to help an individual read, write and have numerical knowledge and to be able to function effectively in the society. It is an education that brings one to knowledge of changes in technological and technical world, equips one with the skills, knowledge and attitude needed to be able to identify resources around, creatively and innovatively transforming them to be useful to self and the larger society. Thus, literacy education as a non- formal education inculcates on the learner the trait of risk-taking, innovation and co-ordination of factors of production for the sole aim of creating new product or services. The creation of these services is central to entrepreneurial development. Chang and Chan (2009) aptly observed that entrepreneurship education increases entrepreneurial self-efficacy, self-employment, risk taking attitude of entrepreneur that creates huge business opportunities and train people with innovative enterprise skills to take the opportunities for starting new entrepreneurial activities. Interestingly, several empirical studies have been conducted on the importance of entrepreneurship education (Ogundele and Akingbade, 2012; Mitra and Abubakar 2011; Robson and Haugh, 2009), yet none of these studies was able to establish the basis of integrating literacy education in entrepreneurial development which is central to this study. Moreso, realising the importance of literacy education, there is need to translate written information to practice through entrepreneurial development, hence the need for repositioning literacy education programme in Rivers State.

\section{Statement of the Problem}

It is generally acknowledged that literacy education is a programme that unlocks the clientele from ignorance. These clienteles are provided with the skills of reading, writing and numeracy to addressing varying needs. One of such needs 
is entrepreneurial skills. These skills afford individuals to be creative, innovative and entrepreneurial. By this, he or she becomes an asset to the society. It is also not unlikely that studies to ascertain the importance of entrepreneurial development have been conducted by various scholars in Nigeria. As to whether literacy education programme has been integrated in the enhancement of entrepreneurial education in the country, such studies to the knowledge of the researchers have not been conducted. This lacuna has provided a knowledge gap which this study intends to fill. In spite of the contributions of literacy education in human capacity development there is need to ascertain the extent these entrepreneurial skills are taught in literacy education programme especially in Rivers State. The problem of this study therefore is to critically investigate how literacy education programme can be repositioned for the attainment of entrepreneurial development in Rivers State.

\section{Purpose of the Study}

The aim of this study was to determine how literacy education programme can be repositioned for entrepreneurial development in Rivers State. Specifically, the study sought to:

1. Determine the extent entrepreneurial skills are taught in literacy education programme in Rivers State.

2. Examine the relevance of literacy education programme in the teaching and learning of entrepreneurial skills in Rivers State.

\section{Research Questions}

The following research questions are posed in the study:

1. To what extent are entrepreneurial skills taught in literacy education programme in Rivers State?

2. What are the relevance of literacy education programme in the teaching and learning of entrepreneurial skills in Rivers State?

\section{Hypotheses}

The following null hypotheses are formulated and tested at .05 level of significance in the study.

$\mathrm{Ho}_{1}$ : There is no significant difference in the mean ratings of facilitators and learners on the extent entrepreneurial skills are taught in literacy education programme in Rivers State.

$\mathrm{Ho}_{2}$ :There is no significant difference in the mean ratings of facilitators and learners regarding the relevance of literacy education programme in the teaching and learning of entrepreneurial skills in Rivers State.

\section{Method and Materials}

The descriptive survey research design was adopted in the study. This design sought the opinions of respondents on how literacy education prgramme can be repositioned for the realisation of entrepreneurship development in Rivers State. This method was used as the study is perceptual in nature. The study population was 1,231 respondents made up of facilitators and learners in 18 centres from Ogba Egbema Ndoni, Emohua and Eleme Local Government Areas of Rivers State. Breakdown of the population further revealed there are 70 facilitators and 1,161 learners. Out of this population, a sample size of 302 was drawn for the study. This comprised 70 facilitators and 232 learners (20\% of learners' population) using purposive and stratified sampling techniques. Data collecting instrument for the study was titled, Questionnaire on Repositioning Literacy Education Programme and Entrepreneurial Development (QRLEPED), weighted on a- four point rating scale. The instrument was validated by three experts in the area of study from the University of Nigeria, Nsukka. The reliability co-efficient of .83 was obtained after a trail test using the Cronbach Alpha to determine the reliability of the instrument. Out of the 302 copies of questionnaire that were administered by the researchers to respondents at their designated centres within a period of two weeks, 297 copies were duly filled and used for the analysis.

The mean and standard deviation of descriptive statistics were employed in answering the research questions. With a criterion mean of 2.50, an item was considered as agreed, while below 2.50 was disagreed. The level to which items were rated is as follows:

$3.50-4.00$ very high extent

$2.50-3.49$ high extent 
$2.00-2.49$ low extent

$1.00-1.99$ very low extent

Similarly, the null hypotheses were tested at .05 level of significance using the t-test statistic of inferential statistics. The existence of no significant difference was that when the calculated t-table value is less than the table value the null hypothesis is accepted. Whereas, a null hypothesis was rejected when the calculated t-value is greater than the t-table value.

\section{Results}

Table 1: Mean Ratings of respondents on the extent entrepreneurial skills are taught in literacy education programme

\begin{tabular}{|c|c|c|c|c|}
\hline \multirow[b]{2}{*}{ S/No Item } & \multicolumn{2}{|c|}{ Facilitators } & \multicolumn{2}{|l|}{ Learners } \\
\hline & $\left(\begin{array}{c}\bar{x} \\
n=70\end{array}\right)$ & Remark & $\left(\begin{array}{c}\bar{x} \\
n=227\end{array}\right)$ & Remarks \\
\hline Knitting, painting weaving etc are taught in literacy education programme & $2.39(.79)$ & Low & $2.22(.78)$ & Low \\
\hline Knitting, painting, weaving, etc are practically taught in the programme & $2.47(.76)$ & Low & $2.31(.76)$ & Low \\
\hline 3. Knitting, painting, weaving are theoretically taught in the programme & $2.41(.77)$ & Low & $2.26(.71)$ & Low \\
\hline 4. Knitting, painting, weaving, etc are regularly taught in the programme & $2.36(.78)$ & Low & $2.12(.74)$ & Low \\
\hline Knitting, painting, weaving, etc are taught in few literacy education centres. & $2.47(.78)$ & Low & $2.45(.80)$ & Low \\
\hline 6. Learners are sent by facilitators to acquire practical skills outside literacy centres. & $2.69(.58)$ & High & $2.58(.70)$ & High \\
\hline Cluster Mean & 2.47 & Low & 2.32 & Low \\
\hline
\end{tabular}

* Figures in bracket are standard deviation

Respondents in table 1 indicate low extent for items 1,2,3,4 and 5 with mean scores of $(2.39,2.22),(2.47,2.31), 2.41$, $2.26),(2.36,2.12)$ and $(2.47,2.45)$ respectively for facilitators and the learners. Item 6 has the mean score of high extent $(2.69,2.58)$ for both respondents. The cluster mean of 2.47 for facilitators and 2.32 for learners shows that the level at which entrepreneurial skills are taught in literacy education programme in Rivers State was low.

Table 2: Mean Ratings of respondents on the relevance of literacy education programme in teaching-learning of entrepreneurial

\begin{tabular}{|c|c|c|c|c|}
\hline \multirow[b]{2}{*}{ S/No Item } & \multicolumn{2}{|l|}{ Facilitators } & \multicolumn{2}{|l|}{ Learners } \\
\hline & $\left(\begin{array}{c}x \\
x \\
n=70\end{array}\right)$ & Remark & $\left(\begin{array}{c}\bar{x} \\
n=227\end{array}\right)$ & Remarks \\
\hline Awareness creation on entrepreneurial skills is promoted & $3.06(.63)$ & Agreed & $3.05(.64)$ & Agreed \\
\hline Enhancement of learners skills for economic development & $3.13(.68)$ & Agreed & $2.85(.66)$ & Agreed \\
\hline 9. Application of entrepreneurial skills is enabled & $3.14(.67)$ & Agreed & $3.03(.74)$ & Agreed \\
\hline 10. Enhancement of learners skills for self reliance & $3.33(.58)$ & Agreed & $3.09(.68)$ & Agreed \\
\hline 11. Exposure of learners to creativity & $3.04(.71)$ & Agreed & $3.01(.64)$ & Agreed \\
\hline Exposure of learners to risk taking in business & $3.20(.65)$ & Agreed & 2.92(.74) & Agreed \\
\hline Cluster Mean & 3.15 & Agreed & 2.99 & Agreed \\
\hline
\end{tabular}

* Figures in bracket are standard deviation

Table 2 reveals that items 7 (3.06, 3.05), $8(3.13,2.85), 9(3.14,3.03), 10(3.33,3.09), 11(3.04,3.01)$ and $12(3.20,2.92)$ for both facilitators and learners are agreed. With the cluster mean of 3.15 and 2.99 for both respondents the table shows that literacy education programme has immensely contributed to the teaching-learning of entrepreneurial skills in Rivers State.

Table 3: t-test analysis of significant difference between the mean ratings of facilitators and learners on the extent entrepreneurial skills are taught in literacy education program

\begin{tabular}{lccccccc}
\hline Respondents & No of Respondents & $\bar{x}$ & SD & Df & $t_{\text {cal }}$ & $t_{\text {crit }}$ & Decision \\
\hline Facilitators & 70 & 2.47 & .30 & & & & \\
Learners & 227 & 2.32 & .27 & 295 & .42 & 1.96 & Accepted \\
\hline & & & & & & \\
& 180 & & & & &
\end{tabular}


With the calculated t-value (.42) less than the critical t-value (1.96) at .05 level of significance and df (295), the null hypothesis is hereby accepted. This implies that significant difference was not found in the mean ratings of facilitators and learners regarding the extent entrepreneurial skills are taught in literacy education programme in Rivers State.

Table 4: t-test analysis of significant difference between the mean ratings of facilitators and learners on the relevance of literacy education programme on the teaching learning of entrepreneurial skills

\begin{tabular}{lccccccc}
\hline Respondents & No of Respondents & $\bar{x}$ & SD & Df & $\mathbf{t}_{\text {cal }}$ & $\mathbf{t}_{\text {crit }}$ & Decision \\
\hline Facilitators & 70 & 3.15 & .33 & & & & \\
Learners & 227 & 2.99 & .28 & 295 & 3.93 & 1.96 & Rejected \\
\hline
\end{tabular}

Since the calculated t-value (3.93) is greater than the critical t-value (1.96) at .05 level of significance and df (295), the null hypothesis which states that there is no significant difference in the mean ratings of facilitators and learners with regard to the relevance of literacy education programme and the teaching-learning of entrepreneurial skills in Rivers State is hereby rejected.

\section{Discussions}

Findings in research question one revealed that literacy skills are taught in literacy education programme to a low extent. Respondents indicated that some literacy skills such as knitting, painting and weaving were neither taught practically nor theoretically in the programme, hence, learners were usually encouraged to acquire these skills outside literacy centres by facilitators. The low application of entrepreneurial skills in literacy education is not unconnected with the fact that the programme is predominantly seen as the acquisition of skills of reading, writing and numeracy. To this end, UNESCO (2014) enumerated the benefits of literacy as helping the learners to get knowledge and skills that are useful in their everyday life activities.

In research of question two, findings revealed that literacy education programme has enormously contributed to teaching and learning of entrepreneurial skills in Rivers State. Affirming this result, respondents indicated that in enhancing their awareness level of entrepreneurial skills, learners were exposed to different skills for several purposes such as economy development, self reliance, creativity as well as risk taking in business. The huge contributions of literacy education programme is attributable to the fact that it is the pivot on which every other development is anchored. Indabawa (1995) gave credence to the findings when he saw literacy as the ability to acquire the skills of reading, writing and numeracy in local or foreign language for effective and efficient functioning of individuals in the activities they involve themselves in the society. One of such activities was rightly captured by Chang and Chan (2009) that entrepreneurship education increases entrepreneurial self efficacy, self employment and risk taking attitude of entrepreneur.

Findings further indicated that significant difference was not found in the mean ratings of facilitators and learners regarding the extent entrepreneurial skills were taught in literacy education programme in Rivers State. The existence of no significant difference between the respondents is an indicative that they share similar views on the variables. These respondents share some views with Omoruyi and Omage (2013) that the purpose of literacy is to liberate man from restrains, limitations of ignorance and dependence.

In terms of relevance of literacy education programme in the teaching and learning of entrepreneurial skills, findings indicated that significant difference was found between the mean ratings of facilitators and learners. The presence of significant difference suggests that both respondents have diverse opinions on the contributions of the literacy education programme in the teaching and learning of entrepreneurial skills. In line with the findings, Kaufman and Kraay (2008) submit that literacy is the heart of basic Education For All (EFA) and essential for eradicating poverty among others.

\section{Conclusion}

In view of the findings of the study, the following conclusions were drawn.

The extent to which entrepreneurial skills were taught in literacy education programme in Rivers State was low. Hence learners were not exposed to entrepreneurial skills. Literacy education programme has significantly contributed to the teaching and learning of entrepreneurial skills in Rivers State. Through the applications of literacy skills, individuals' level of awareness and curiousity in innovation, creativity and entrepreneurship are enhanced. 


\section{Recommendations}

Based on the findings of the study and conclusion drawn, the following recommendations are made;

1. Organisers of literacy education programme should ensure that the entrepreneurial skills enshrined in literacy curriculum be vigorously been taught in the programme.

2. Adequate facilities that will promote the teaching and learning of entrepreneurial skills should be provided by organisers of literacy education programme.

3. Government should ensure compliance through adequate monitoring and supervision of content in literacy education programme delivery.

4. Community sensitisation on the importance of literacy education using different mass media should be carried out by both government and non-governmental organisations.

5. Facilitators should be encouraged from time to time to enroll into professional development and training.

\section{References}

Adenutsi, D.E. (2009). Entrepreneurship, job creation, income empowerment and poverty reduction in low-income economies. Mumih Personnel Repec Archive (MRRA), 29569, 1 - 21.

Anho, J.E. (2011). Impact of entrepreneurship education and training on university graduates for sustainable development. In E.A. Arubayi, N.E. Akpotu \& E.P. Oghuvbu (Eds). A book of reading: education and training for entrepreneurship.

Chang, M.Y \& Chan, W.S. (2009). The effectiveness of entrepreneurship education in Malaysia. Education + training 51: 555 - 566.

Coulter, M. (2001). Entrepreneurship in action. N.J: Prentice-Hall, Upper Saddle Rover.

Indabawa, S.A. (1995). Literacy and development in the developing world: A critique of the position of the German adult education association (D.V.V). Kano Journal of Education Studies (KAJEST).

Kaufmann, D. \& Kraay, A. (2008). Governance indicators where are we? Where should we be going? The global governance group. World Bank Institute and the Macro-economics.

Mitra, J. \& Abubakar, Y. (2011). Knowledge creation and human capital for development: The role of graduate entrepreneurship. Education+ training, 53: 462-479.

Ogundele, O. \& Akingbade, W.A. (2012). Entrepreneurship training and education as strategic tools for poverty alleviation in Nigeria. American international journal of contemporary research, 2:148-156.

Omoruyi, F.E.O. \& Omage, S.A. (2013). Literacy as a panacea for good governance. A paper presented at the Biennial conference of the reading association of Nigeria held in 2012 at Abuja.

Robson, P.J. \& Haugh,H.M. (2009). Entrepreneurship and innovation in Ghana: Enterprising Africa. Small business economics, 32: $331-350$

UNESCO (1997). Small relevance of entrepreneurship education: A political economy of adult education in Nigeria. Ibadan: University Press.

UNESCO (2014). Training manual for facilitators in non-formal education.Abuja: UNESCO 